\title{
Honey bee colony mortality and productivity with single and dual infestations of parasitic mite species
}

\author{
Danielle L. DownEY*, Mark L. WINSTON** \\ Department of Biological Sciences, 8888 University Drive, Simon Fraser University, \\ Burnaby, BC, V5A 1S6, Canada
}

(Received 22 June 1999; revised 23 August 2000; accepted 28 August 2001)

\begin{abstract}
Colony mortality and productivity were compared between honey bee (Apis mellifera) colonies infested by zero, one or both species of parasitic mites (Acarapis woodi or Varroa destructor). Mortality, bee and mite populations, sealed brood, and stores were monitored for 16 months, beginning in May. By the following March, 5 out of 6 colonies with both mites were dead, but no other colonies died until September, when 3 out of $4 \mathrm{~V}$. destructor colonies were dead. Dually infested colonies initially had more honey stores, but were dead by March. At that point $V$. destructor colonies had significantly less worker brood, fewer adult bees and more honey than colonies with no mites or tracheal mites (Acarapis woodi). The colonies with tracheal mites $(n=9)$ and no mites $(n=8)$ did not differ in any productivity parameter measured. These results suggest a synergistic interaction between tracheal and $V$. destructor mites, treatments against tracheal mites should be applied in dually infested colonies, even if tracheal mites alone are not having an impact.
\end{abstract}

Varroa destructor / Acarapis woodi / colony productivity / colony mortality

\section{INTRODUCTION}

The honey bee Apis mellifera L. is important for honey production and pollination world-wide, and thus, this species has been moved and traded across the globe. Movement of bee stock has facilitated distribution of parasites and pathogens that exploit the homeostatic environment of honey bee colonies, and these have become critical management problems. The externally parasitic mite, Varroa destructor Anderson and Trueman (2000), and the honey bee tracheal mite, Acarapis woodi Rennie, are two parasites that are primary concerns for beekeepers. Varroa destructor is a highly destructive pest, responsible for reduced honey and brood production (DelfinadoBaker, 1988), precocious foraging (Schneider, 1986), increased drift (Sakofski, 1990),

* E-mail: ddowney @ sfu.ca

** Correspondence and reprints

E-mail:winston@sfu.ca 
higher bee mortality in winter (Kovac and Crailsheim, 1988) and considerable colony mortality (De Jong, 1997). The original host of this mite is the Asian honey bee, Apis cerana Fabr., and as the mite enters Apis mellifera populations worldwide, beekeepers experience substantial colony loss and damage (Matheson, 1994; Kraus and Page, 1995; Finley et al., 1997).

Tracheal mites are pests of more variable impact. Several British studies of the tracheal mite suggest that it may not be a current threat to honey bee colonies, although it is thought to be responsible for devastating colony losses in the early century, then called the Isle of Wight Disease (reviewed in Bailey and Ball, 1991). In North America, especially in colder climates, studies indicate that tracheal mites are a more serious pest. They can reduce honey yield (Eischen et al., 1989) and brood production (Eischen, 1987), increase winter mortality (Otis et al., 1988, 1992) and are associated with higher bacterial and viral disease incidence (Bailey and Ball, 1991). V. destructor mites are consistently more virulent than tracheal mites, often killing a colony within two years if left untreated (Matheson, 1994; Kraus and Page, 1995). This, combined with variable tracheal mite impact and sampling methods requiring a microscope, results in many beekeepers focusing management attention on $V$. destructor and neglecting tracheal mite sampling and treatment.

$V$. destructor ia a relatively large ectoparasite that develops and reproduces in the cell of a developing bee. Adult females enter the cell just before it is capped for pupation, lay eggs and puncture the bee to feed on its hemolymph. The mite and its offspring usually do not kill the bee, they emerge with it to undergo a phoretic period on adult bees before they enter another cell to reproduce. The tracheal mite carries out its whole life cycle in the trachea of adult honey bees, puncturing the trachea and feeding on hemolymph, reproducing as long as the bee lives (Pettis and Wilson, 1996). Tracheal mite progeny leave the trachea only to find another susceptible host. Mite studies to date have investigated $V$. destructor and tracheal mites independently, but as they continue to spread, it is common to have both mites in one colony.

The objective of this project was to assess the impact of dual infestation on honey bee colonies. Since both mites feed on bee hemolymph and can have some similar effects on colonies independently, we predicted that dual infestation would have an additive or synergistic effect on colony productivity and mortality.

\section{MATERIALS AND METHODS}

All experiments were conducted in the Vancouver region of British Columbia, Canada. Experimental colonies were established from package bees imported from Vancouver Island, BC, then a mite free area. Packages were sampled for tracheal mites, none were found. Each package consisted of $1 \mathrm{~kg}$ of bees and a queen of Australian origin, collected on 7 May and installed on 8 May. At installation, each colony received two frames of honey, sugar syrup ad libitum, and the same amount and type (worker, drone) of comb or foundation. Treatments were assigned to 40 colonies, but due to inclement weather, colonies were inaccessible until after several had swarmed. After colonies that swarmed were removed, treatments were: no mites $(n=8), V$. destructor mites $(n=4)$, tracheal mites $(n=9)$ and both mites $(n=6)$. Tracheal mite infestations were established by taking bees from colonies with known tracheal mite infestations (about 50\%), pooling them in a large screen box and adding $400 \mathrm{~g}$ of these bees to each colony on 20 May. Colonies that were not in treatment groups with tracheal mites received $400 \mathrm{~g}$ of bees from uninfested colonies. The introduced bees were sprayed lightly with dilute sugar syrup and placed on newspaper atop the frames of a colony. 
Varroa destructor infestations were established by removing frames of bees near eclosion from colonies known to have high mite levels, placing them in an incubator and collecting newly emerged bees with mites into petri dishes. These petri dishes were opened and inverted on the top bars of the colony, so the bees could crawl in and introduce mites. In this fashion, colonies in treatment groups that required $V$. destructor infestation received 86 mites each on 20 May.

Both mites spread rapidly within an apiary, so to preserve treatment integrity Apistan strips were placed in colonies that were not to have $V$. destructor and menthol and grease patties were applied to colonies that were to be tracheal-mite free. Menthol was applied once on 11 June, and the other treatments were applied in the spring and fall 1997 and 1998. Apistan does not impact transfer or reproduction of tracheal mite populations (Pettis et al., 1988; Melathopoulos et al., 2000), and menthol vapor does not effect $V$. destructor survival at the dose used (reviewed in Imdorf et al., 1999). Apistan, menthol and grease patties have no effects on colony productivity or bee behavior (Westcott and Winston, 1999). Colonies were also fed sugar syrup medicated with antibiotics; oxytetracycline hydrochloride and bicyclohexylammonium fumagillin, to prevent foulbrood and nosema. Pollen supplements were given at installation and again in February 1998.

Colony productivity was assessed three times, 18 August 1997, 25 March 1998 and 24 July 1998. Measurements were taken by holding a plastic transparent grid divided into 32 equal squares over a frame and tabulating the number of grid squares of sealed worker brood area, sealed drone area, honey, pollen, and adult bees. Adult bees were measured before daily foraging started. Colonies also were weighed at assessment, and mite populations sampled. Tracheal mite sampling was done by collecting bees from each colony into ethanol, dissecting 30 of them under a microscope, and inspecting the prothoracic trachea for mites. $V$. destructor sampling was done with sticky boards, placing a piece of corrugated plastic coated with a petroleum jelly/vegetable oil (1:1 vol.) blend covered with a plastic mesh screen in the bottom of each hive. This board was removed from the hive after 24 hours to count the mites that fell and were trapped. Colonies were sampled in between Apistan treatments, "mite drop" reflects natural levels in all measurements. Colony mortality was assessed every $2-3$ weeks by opening the colonies.

Statistical analysis was done in SAS 6.12 and SAS JMP IN 3.1.5. Mite treatments were compared among two groups, colonies seeded with a mite species and those not seeded. One-way analysis of variances (ANOVA) were then done for $V$. destructor and tracheal mites on each date. Colony productivity was analyzed using a one-way ANOVA for each parameter, dates were analyzed separately. Survivorship curves were compared using a Lifetest procedure in SAS, and a Fisher's Exact test was used to compare treatment group mortality.

\section{RESULTS}

Mite treatments were successfully established using the seeding method, but by the end of the experiment there was considerable tracheal mite drift. Tracheal mite populations in seeded colonies were significantly higher than in un-seeded colonies for at least 10 months, including a summer and winter (Fig. 1). Varroa destructor populations were always significantly higher in colonies seeded with $V$. destructor than in un-seeded colonies (Fig. 2).

There was no colony mortality during the first season, but on the March assessment (after the first winter, 10 months after installation), 5 out of 6 colonies with both mites were dead (Fig. 3A). On the following assessment in September, 3 of $4 \mathrm{~V}$. destructor colonies were dead, and one queen was 


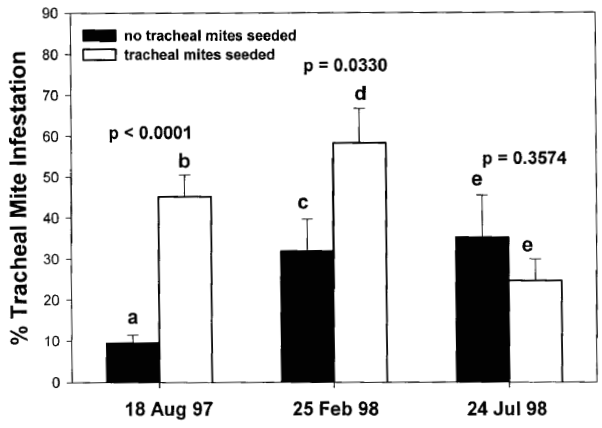

Figure 1. Tracheal mite infestation levels (mean \pm SE) in colonies seeded with tracheal mites $(n=15)$ and those not seeded $(n=12)$. Letters indicate means that were significantly different $(P<0.05)$ using Tukey-Kramer's test.

lost in the colonies with no mites (Fig. 3B). Probability of survival was significantly different among treatment groups (Lifetest, $P<0.0001$, Chi-Sq = 23.72). Although mortality was not different among the no mites and tracheal mites colonies, nor in the $V$. destructor and both mite treatments (two tail Fisher's Exact test, $P=0.4706$ and $P=0.5333$, respectively), these pairs were significantly different from each other (two tail Fisher's Exact test, $P<0.001)$.

In the first year, colonies with both mites had significantly more honey than colonies with no mites by August, and single mite treatments had intermediate honey stores (Fig. 5, $P=0.0330, F=3.4553$ ). No other parameters were significantly affected by mite treatment until after winter (Figs. 4 and 5). In March, most colonies with both mites were dead, so only the three remaining treatments were compared. Colonies with $V$. destructor had significantly less worker brood $(P=0.0003, F=13.7140)$ (Fig. 4), and fewer adult bees $(P=0.0261, F=4.5503)$ (Fig. 4). Colonies with $V$. destructor had more honey than colonies with no mites, and tracheal mite colonies had intermediate honey stores $(P=0.0194, F=5.0142)$ (Fig. 5). On the final assessment in July, the colonies remaining, tracheal mite and no mite treatments, showed no significant differences in any of the parameters measured, and there were statistically indistinguishable tracheal mite populations established in both treatments (Fig. 1).

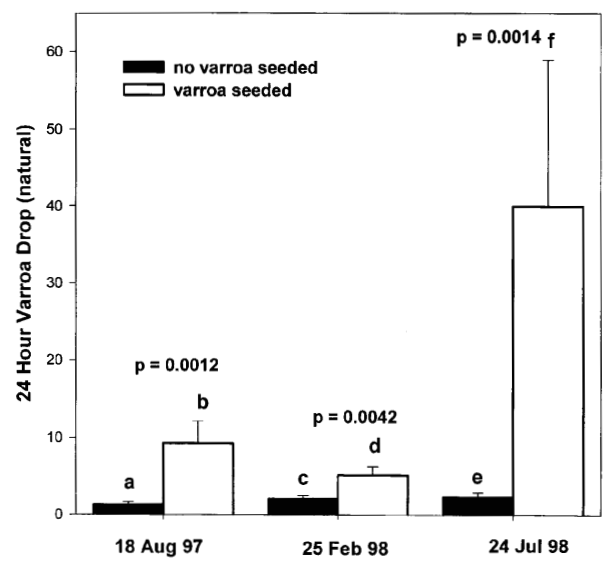

Figure 2. Varroa destructor mite drop measured for 24 hours with no acaricide (mean \pm SE) in colonies seeded with $V$. destructor $(n=10)$ and those not seeded $(n=17)$. Letters indicate means that were significantly different $(P<0.05)$ using Tukey-Kramer's test.

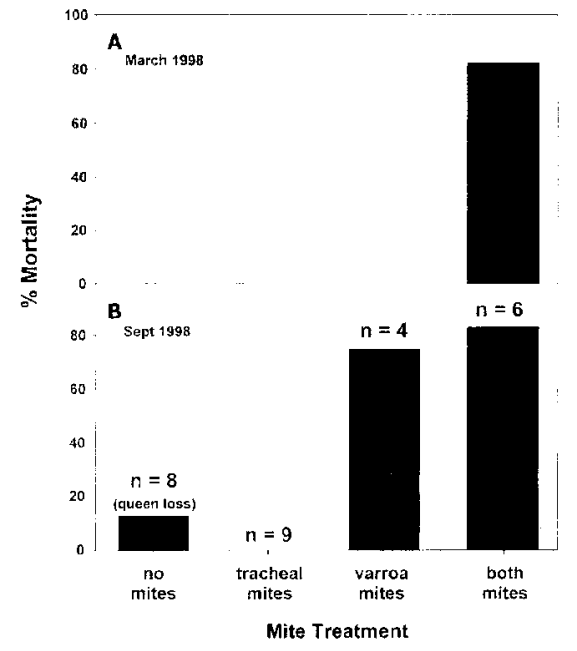

Figure 3. Colony mortality (\%) in March and September 1998 (Lifetest, $P<0.001$ ). 


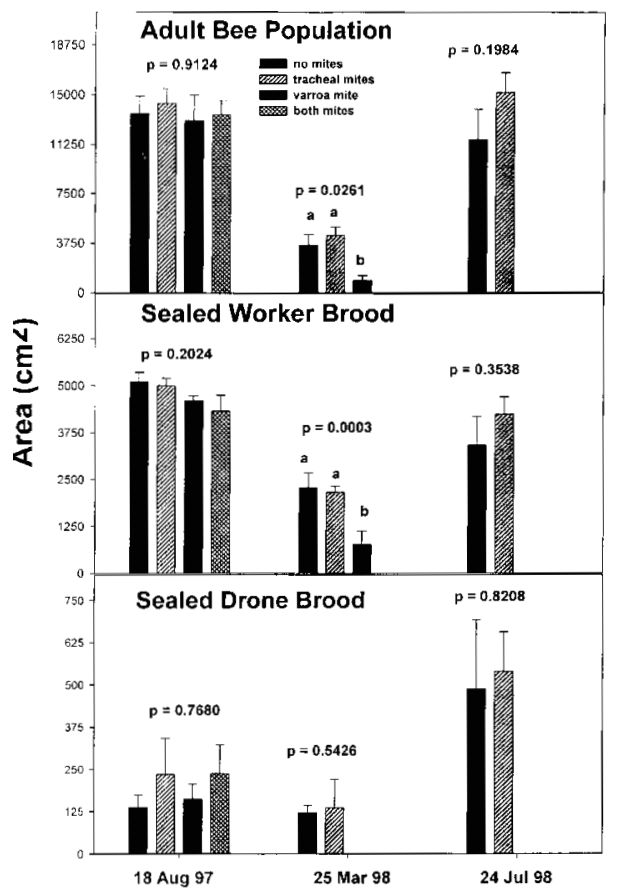

Figure 4. Adult bee population, sealed worker and drone brood analyzed separately with oneway ANOVAs on each date. Letters indicate means that are significantly different $(P<0.05)$ using Tukey-Kramer's test.

\section{DISCUSSION}

Colonies infested with both mite species sustained considerably greater mortality over their first winter than colonies with just one mite species or uninfested colonies. Colonies with $V$. destructor survived the spring and died in late summer, while tracheal mite and no mite colonies survived. These results support the hypothesis of a synergistic effect of tracheal mites and V. destructor on colony mortality, although there is a regrettably limited sample size. The mechanism of this synergy remains to be investigated. Both mites deprive the bee of hemolymph and protein (Bailey and Ball, 1991; De Jong et al., 1982; Kovac and Crailsheim, 1988) and both species are also associated with higher levels of bacterial

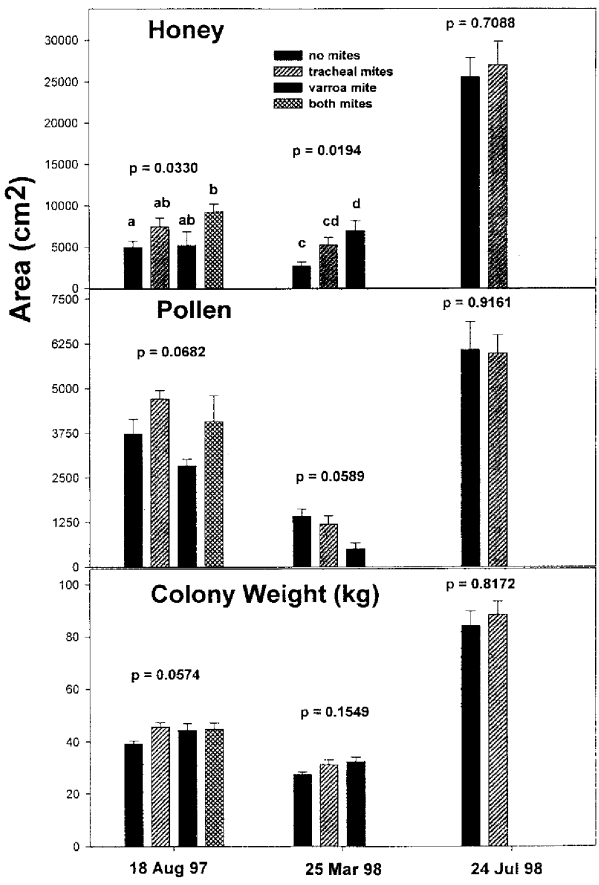

Figure 5. Colony weight, honey and pollen stores analyzed separately with one-way ANOVAs on each date. Letters indicate means that are significantly different $(P<0.05)$ using TukeyKramer's test.

and viral pathogens in bee hemolymph (Allen and Ball, 1996). Genetic variability is known to affect mite impact (Page and Gary, 1990; Frazier et al., 1995) and mortality due to mites often has been discussed in relation to environmental conditions (Eischen, 1987; Eischen et al., 1989; Harbo, 1993). Further investigation of this hypothesis should consider these factors.

It is noteworthy that mortality was high in the mild climate of Vancouver, BC, with rainy winters and little snow. Average coastal temperatures are much warmer than most of Canada and the US at similar longitudes, and if mites were causing death under these conditions, mortality would have likely been much higher under more severe winter conditions. Thus, some of the impact attributed to $V$. destructor in other regions could be 
due to dual mite infestations. Controlling tracheal mites could reduce $V$. destructor impact by buying beekeepers a substantial and critical margin of time; in this study the colonies with both mites are dead by spring. In contrast, colonies managed to prevent tracheal mites survived the spring and summer, allowing a window of opportunity to apply miticide.

Comparisons of colony productivity show that in the first season, colonies with both mites had more honey than colonies with no mites. Perhaps mite stress causes colonies to gather more resources. However, no similar effect was seen in a study comparing individual forager behavior among bees with tracheal and $V$. destructor mite parasitism (Downey et al., 2000). Alternatively, colonies with mites may use less honey, due to lower population size, but this difference was not reflected in brood or adult population measurements.

Varroa destructor infestation was associated with less brood, fewer bees and more honey by spring, one year after establishment. These colonies were failing, and smaller adult and brood populations resulted in less honey consumption and higher stores. Pollen stores were lower, although statistically this effect was not quite significant $(P=0.06, F=3.3603)$. Tracheal mites colonies also had more honey at this point, possibly a result of using less honey through the winter. Studies by Nasr et al. (1998) indicate that bees with tracheal mites are not able to respire as effectively as uninfested bees to maintain high core temperatures in winter, which would result in less honey consumption.

Tracheal mites often are considered an inconsequential threat, and in the mild West Coast climate colonies with tracheal mites performed comparably to uninfested colonies. However, tracheal mites in colder climates may pose a greater threat and our study revealed that tracheal mites and Varroa destructor are a greater mortality risk to a colony than either mite alone.
As Varroa destructor becomes resistant to fluvalinate (Elzen et al., 1998) it will be increasingly important to reduce the impact of infestation by using integrated approaches, considering the many risks and stresses on any one colony. For example, the synergy these results suggest could mean that it is in beekeepers interests to select bee stock in terms of dual infestation rather than one mite at a time. Honey bees have been selected and bred to tolerate tracheal mite infestation with some success (reviewed in Wilson et al., 1997). However, by supporting a sub-lethal tracheal mite infestation, stock that is tracheal mite tolerant could be more vulnerable to sudden mortality due to dual infestations than stock which beekeepers routinely treat for tracheal mites.

Further study is necessary to confirm that colony management and future mite research should consider not just Varroa destructor, but both mite species and possibly interactions with other bee diseases. In the meantime, colony management and research projects which include assessment of the both mite species avoid misinterpreting phenomena possibly confounded by dual infestation.

\section{ACKNOWLEDGEMENTS}

This study was supported by a Saskatchewan Agri-Food Innovation Fund grant, a Natural Sciences and Engineering Research council operating grant to MLW, and Simon Fraser University Graduate Fellowships. We gratefully acknowledge Heather Higo, Alida Janmaat, and the Simon Fraser University Swarm Team for help maintaining mite and bee populations and assistance during data collection, Bernard Vaissière and Jonathan Gowthorpe for help with final edits, and Adony Melathopoulos for assistance from start to finish.

Résumé - Mortalité dans les colonies d'abeilles et productivité avec infestation par une ou deux espèces d'acariens parasites. L'acarien Varroa destructor Anderson and Trueman, parasite externe de l'abeille 
domestique et Acarapis woodi Rennie, l'acarien des trachées, sont des parasites sérieux des colonies d'abeilles (Apis mellifera L.) où ils induisent, entre autres, mortalité et/ou baisses de rendement en miel. Le but de cette étude était d'évaluer l'impact d'une infestation double.

La mortalité et la productivité ont été comparées entre des colonies d'abeilles domestiques infestées par aucune, une ou les deux espèces d'acariens parasites. Les colonies ont été démarrées avec des paquets d'abeilles d'un kg. Les acariens $A$. woodi ou $V$. destructor ont été ajoutés pour constituer des groupes de traitement, les colonies ont été traitées de façon à ne conserver que l'espèce d'acarien choisi, puis la mortalité et la productivité des colonies ont été suivies durant 16 mois. Des évaluations périodiques ont été faites pour mesurer la population d'abeilles adultes, la surface de couvain operculé, le poids de la colonie, les réserves en miel et en pollen et le niveau d'infestation. Les populations d'acariens ont été constituées et maintenues, malgré une certaine contamination due à la dérive (Figs. 1 et 2). Aucune colonie n'est morte jusqu' au mois de mars suivant le premier hiver, où cinq des six colonies avec les deux espèces d'acariens ont été trouvées mortes. À la fin de l'expérimentation en septembre, trois des quatre colonies avec $V$. destructor étaient mortes, une colonie sur huit avec aucun acarien était morte par perte de la reine et les neuf colonies avec $A$. woodi étaient vivantes (Fig. 3). Au cours de la première saison, les colonies avec les deux espèces d'acariens avaient à l'origine de plus grandes réserves en miel (Fig. 5), mais au printemps lorsque ces colonies sont mortes, les colonies avec $V$. destructor avaient significativement moins de couvain d'ouvrières et moins d'adultes (Fig. 4) et plus de miel que les colonies sans acariens ou avec $A$. woodi. Lors de la dernière estimation, lorsque les colonies avec $V$. destructor ont été retirées parce que mortes, les colonies avec $A$. woodi et celles sans acariens ne pouvaient pas être distinguées statistiquement d'après les paramètres de productivité et des populations d'A. woodi étaient présentes dans toutes les colonies. Ces résultats, bien que limités en ce qui concerne la taille de l'échantillon, la variation génétique et les conditions géographiques, suggèrent une synergie entre $A$. woodi et $V$. destructor du point de vue de la mortalité de la colonie et, même si $A$. woodi seul n'a pas d'impact, il est nécessaire de traiter contre $A$. woodi s'il existe un risque d'infestation double.

Varroa destructor / Acarapis woodi / productivité / mortalité / colonie d'abeilles / double infestation

Zusammenfassung - Sterblichkeit von
Bienenvölkern und ihre Produktivität mit
einfacher und Doppelinfektionen mit
parasitischen Milbenarten. Die Sterb-
lichkeit von Bienenvölkern (Apis mellifera) und ihre Produktivität wurden bei gesunden Völkern und bei Völkern mit einfachem oder doppeltem Befall mit 2 Arten parasitischer Milben (Acarapis woodi, die Tracheenmilbe und Varroa destructor) verglichen. Die Völker wurden aus $1 \mathrm{~kg}$ Paketbienen aufgebaut und behandelt. Anschließend wurden sie entsprechend die Testgruppe mit der erwünschten Milbenart infiziert. Die Sterblichkeit der Völker und ihre Honigerzeugung wurde 16 Monate lang registriert. Außerdem erfolgten regelmäßige Schätzungen, um die Bienenpopulation, verdeckelte Brut von Arbeiterinnen und Drohnen, Volksgewicht, Honig- und Pollenvorräte und die Befallstärke zu messen. Die Milbenpopulation wurde aufgebaut und aufrecht erhalten, obwohl durch Verdriften eine geringe gegenseitige Ansteckung erfolgte (Abb. 1 und 2). Bis März nach der ersten Überwinterung gab es keine Volkszusammenbrüche, aber dann starben 5 von 6 der mit beiden Milben infizierten Völker. Bei der Beendigung des Experiments im September waren 3 von 4 ,Varroa-Völkern“ 
tot. Eins von 8 befallsfreien Völkern starb auf Grund des Verlustes der Königin und kein Volk von den mit Tracheenmilben infizierten Völkern ( $n=9$, Abb. 3$)$. In der ersten Bienensaison hatten Völker mit Tracheenund Varroa-Milben zunächst mehr Honig eingetragen (Abb. 5) aber im Frühjahr, als die Völker mit Doppelinfektion starben, hatten die ,Varroa-Völker“ signifikant weniger Brut, weniger adulte Bienen (Abb. 4) und mehr Honig als die befallsfreien oder mit Tracheenmilben befallenen Völker. Bei der letzten Ablesung, als die ,Varroa-Völker" bereits nach dem Zusammenbruch entfernt waren, waren die befallsfreien Völker in allen gemessenen Parametern nicht von den Völkern mit Tracheenmilben zu unterscheiden. Die Population der Tracheenmilben war bei allen Versuchsvölkern vorhanden. Diese Ergebnisse lassen trotz der geringen Zahl an Versuchsvölkern, der genetischen Variation und den geografischen Bedingungen eine synergistische Interaktion zwischen Tracheen- und Varroa-Milben in Bezug auf die Sterblichkeit der Völker schließen. Auch wenn der Befall von Tracheenmilben allein keinen Einfluss hat, sollte eine Behandlung gegen die Tracheenmilben durchgeführt werden, wenn ein Risiko der Doppelinfektion vorhanden ist.

Varroa destructor / Acarapis woodi / Honigproduktion / Volkssterblichkeit

\section{REFERENCES}

Allen M., Ball B. (1996) The incidence and world distribution of honey bee viruses, Bee World 77 141-162.

Anderson D.L., Trueman J.W.H. (2000) Varroa jacobsoni (Acari: Varroidae) is more than one species, Exp. Appl. Acarol. 24, 165-189.

Bailey L., Ball B.V. (1991) Honey Bee Pathology, 2nd ed., Academic Press Limited, London, England.

De Jong D. (1997) Mites: varroa and other parasites of brood, in: Morse R.A., Flottum K. (Eds.), Honey bee pests, predators and diseases, 3rd ed., A.I. Root Company, Medina, Ohio, USA, pp. 278-327.
De Jong D., de Jong P.H., Gonçalves D.S. (1982) Weight loss and other damage to developing worker honeybees from infestation with Varroa jacobsoni, J. Apic. Res. 21, 165-167.

Delfinado-Baker M. (1988) The tracheal mite of honey bees: a crisis in beekeeping, in: Needham G., Page R., Delfinado-Baker M., Bowman C. (Eds.), Africanized honey bees and bee mites, Halsted Press, Chichester, England, pp. 493-497.

Downey D., Higo T., Winston M. (2000) Single and dual parasitic mite infestations on the honey bee, Apis mellifera L., Insectes Soc. 47, 171-176.

Eischen F.A. (1987) Overwintering performance of honey bee colonies heavily infested with Acarapis woodi (Rennie), Apidologie 18, 293-304.

Eischen F.A., Cardoso-Tamez D., Wilson W.T., Dietz A. (1998) Honey production of honey bee colonies infested with Acarapis woodi (Rennie), Apidologie 20,1-8.

Elzen P.J., Eischen F.A., Baxter J.B., Pettis J., Elzen G.W., Wilson W.T. (1998) Fluvalinate resistance in Varroa jacobsoni from several geographic locations, Am. Bee J. 138, 674-676.

Finley J., Camazine S., Frazier M. (1997) The epidemic of honey bee colony losses during the 1995-1996 season, Am. Bee J. 136, 805-808.

Imdorf A., Klichenmann V., Bogdanov S., Bachofen B., Beretta C. (1995) Toxizität von Thymol, Camphor, Menthol und Eucalyptol auf Varroa jacobsoni Oud und Apis mellifera L. im Labortest, Apidologie 26, 7-31.

Kovac H., Crailsheim K. (1988) Lifespan of Apis mellifera carnica Pollm. infested by Varroa jacobsoni Oud. in relation to season and extent of infestation, J. Apic. Res. 27, 230-238.

Kraus B., Page R.E. (1995) Effect of Varroa jacobsoni (Mesostigmata, Varroidae) on feral Apis mellifera (Hymenoptera, Apidae) in California, Environ. Entomol. 24, 1473-1480.

Matheson A. (1994) The impact of varroa infestation on beekeeping, in: Matheson A. (Ed.), New Perspectives on Varroa, International Bee Research Association, Cardiff, UK, pp. 27-31.

Melathopoulos A.P., Winston M.L., Whittington R., Higo H., Le Doux M. (2000) Field evaluation of neem and canola oil for the selective control of the honey bee (Hymenoptera: Apidae) mite parasites Varroa jacobsoni (Acari: Varroidae) and Acarapis woodi (Acari: Tarsonemidae), J. Econ. Entomol. 93, 559-567.

Otis G.W., Bath J.B., Randall D.L., Linda S.B. (1988) Studies of the honey bee tracheal mite (Acarapis woodi) (Acari: Tarsonemidae) during winter, Can. J. Zool. 66, 2122-2127.

Otis G.W., Scott-Dupree C.D. (1992) Effects of Acarapis woodi on overwintered colonies of honey bees (Hymenoptera: Apidae) in New York, J. Econ. Entomol. 85, 40-46. 
Pettis J.S., Cox R.L., Wilson W.T. (1988) Efficacy of fluvalinate against the honey bee tracheal mite Acarapis woodi, under laboratory conditions, Am. Bee J. 128, 806

Pettis J.S., Wilson W.T. (1996) Life history of the honey bee tracheal mite, Acarapis woodi (Acari: Tarsonemidae), Ann. Entomol. Soc. Am. 89, 368-374.

Sakofski F. (1990) Quantitative investigations on trans fer of Varroa jacobsoni Oud., Proc. Int. Symp. on Recent Research on Bee Pathology, Sept. 5-7, Gent, Belgium Rijksstation voor Nematologie en Entomologie on behalf of Apimondia, Merelbeke, Belgium, 1991, pp. 70-72.
Schneider P. (1986) The influence of Varroa infestation during pupal development on the flight activity of the worker honey bees, Apidologie 17, 366-368.

Westcott L., Winston M.L. (1999) Chemical acaricides in Apis mellifera L. (Hymenoptera: Apidae) colonies: do they cause non-lethal effects, Can. Entomol. (in press).

Wilson W.T., Pettis J.S., Henderson C.E., Morse R.A. (1997) Tracheal mites, in: Morse R.A., Flottum K. (Eds.), Honey bee pests, predators and diseases, 3rd ed., A.I. Root Company, Medina, Ohio, USA, pp. 253-277. 